\title{
Domestic tourists' mind-set towards Responsible Tourism Management: a case study on Cox's Bazar, Bangladesh
}

\author{
Mohammad Ruhual Amin \\ Assistant Professor, Department of Tourism and Hospitality Management \\ University of Dhaka \\ Dhaka-1000, Bangladesh \\ E-mail: m.r.aminthm.du@gmail.com
}

\begin{abstract}
In spite of being a significant stakeholder in the sustainable and responsible tourism development and management process, worldwide only a few studies exclusively tried to find out tourists' attitudes towards them. Moreover, they are principally missing in case of developing and least developed countries where the domestic tourism market is more significant than international market. Besides, in Bangladesh, no study exists that tried to discover the domestic tourists' attitudes towards Responsible Tourism Management (RTM) and to its Triple Bottom Line (TBL) components. So, this research was a step to fulfill the recognized gaps, as well as, an initiative to append the empirical findings to the existing RTM literature. After conducting an extensive literature review, this study followed both the exploratory (in-depth interview) and descriptive (survey) research designs to conduct it. Further, this study used Descriptive statistics (Frequency distribution and cross tabulation) and multivariate dependence data analysis technique (multiple regression analysis) to analyze the data collected from the 385 sample respondents using stratified random sampling. Based on the findings, the present study support that, Bangladeshi tourists have positive attitudes to each of the TBL components and to RTM, however, to enhance their attitudes towards RTM and to TBL components, scopes are still available. This study also suggests including tourists' sociodemographic characteristics whilst measuring their attitudes, as their attitudes considerably vary as a result of variation in their socio-demographic characteristics. With the support of and reference to this study, the Destination Management Organizations (DMOs) can work on each of the TBL components to enhance the positive attitudes of Bangladeshi tourists towards Responsible Tourism practices at Cox's Bazar (CB). Moreover, the frameworks of this study also useful to study similar subject areas at other destinations in Bangladesh. This study on CB, Bangladesh also contributes to the RTM literature and minimizes the known literature gap for developing countries.
\end{abstract}

Keywords-Responsible Tourism Management; Triple Bottom Line; Domestic Tourism; Domestic Tourist; Attitude

\section{INTRODUCTION}

Tourism industry worldwide is predominantly domestic in nature [1]. There is a general agreement within the industry that by all account, domestic travel and tourism is more significant and generates up to ten times higher arrivals than the international market [2]. Supportively, around the world, many scholars support and outline the 10:1 ratio of domestic versus international tourist $[3,4,5]$. Moreover, the United Nation World Tourism Organization (UNWTO) forecasted that the growth of domestic tourism will be particularly significant in many developing countries over the next 20 years [6]. Similarly, United Nations (2007) stated that domestic tourists appeared and will continue as a significant market for many developing countries, particularly in the of North East, South, and South East Asia regions [7]. According to the World Travel \& Tourism Council (WTTC), in 2015, $72.9 \%$ of the Asia-Pacific's direct travel and Tourism GDP was generated from the domestic travel and tourism spending [8] and it was recorded as $80.3 \%$ for the South Asia region [9].

Developing and Least Developed Countries (LDCs) who are looking for alternative, less exploitive forms of tourism development should encourage domestic tourism rather than multinational, large capital intensive international tourism [6, $10,11]$. Although international tourism is growing in many developing countries, development of domestic tourism is much more helpful for bringing stability in the volatile industry and sustainable development by bridging seasonality, creating job opportunity, and ensuring a stable service sector [6]. Moreover, it is firmly claimed and strongly believed by many scholars and industry experts that, planned development of domestic tourism is the major prerequisite of developing well-built Sustainable tourism (ST) at a destination $[4,6,5]$.

In many developing and LDCs, the key factors behind the surge of domestic tourism are the ascending middle class with rational prosperity, higher disposable income, and their enhanced wish to travel $[6,12,10,5]$. Following similar trends, domestic tourism market of Bangladesh is steadily growing with an average annual rate of about $25 \%$. Major reasons behind this remarkable growth are the rising trend of the middle income population with higher education, higher disposable income, and their growing interest to participate in tourism and leisure activities [13]. Since the 1990, the case study site, Cox's Bazar (CB) in Bangladesh, which is $120 \mathrm{~km}$ in length and the world's largest uninterrupted natural sandy sea beach $[14,15,16]$, faced a surge in its tourism 
development. It is the prime and the most visited tourist destination in Bangladesh [13, 17, 18]. It is often known as the tourist capital of Bangladesh [19, 17]. In 2013, more than 1.3 million tourists visited $\mathrm{CB}$ and its adjunct areas where more than $95 \%$ of them were domestic tourists [13].

Due to having the potential of making significant positive impacts on the local economy, society and environment; development of sustainable tourism (ST), responsible tourism (RT) and their useful practices are the most concerned and discussed topic in the recent tourism study [20]. However, in spite of being a major stakeholder in ST and RT development and management process [21, 22, 23], tourists' attitudes towards RT development and/or management and towards its Triple Bottom Line (TBL) components have been considered by very few studies and mostly missing in case of developing and LDCs context [24, 21, 22, 25]. Moreover, in Bangladesh, no study exists which utterly tried to find out domestic tourists' or other stakeholders' attitudes towards Responsible Tourism Management (RTM) and to its TBL components [13]. The UNWTO Commission for South Asia reported, in the South-Asian region, domestic tourism is ignored both as an area of development and as a subject of research [26]. So, this intended research was a step to fulfil the identified gaps, as well as, an initiative to add the empirical findings to existing RTM literature.

To address the aforementioned research gap, the present study set the aim to find out domestic tourists' attitudes towards RTM at CB, Bangladesh. The research also aims to find out whether their attitudes vary in terms of sociodemographic variables in order to identify the most appropriate target market for maximising the positive impacts of domestic tourism whilst minimising the negative ones. Moreover, this study also focused on the following specific objectives:

1. Measure the influence of each TBL component (social, economic, and environmental) on the domestic tourists' attitudes formation towards RTM.

2. Draw conclusions and formulate recommendations about which component(s) of the TBL should be considered by Destination Management Organizations (DMOs) to improve tourists' positive attitudes towards RT development at CB.

3. Draw conclusions and formulate recommendations about how the DMOs at $\mathrm{CB}$ can improve the tourism experience at $\mathrm{CB}$, based on the understanding of the market characteristics.

\section{LITERATURE REVIEW}

Since 1970s, RT started to be considered as one of the 'new forms of tourism' and placed itself into the alternative tourism paradigm [27]. Later in 1989, to classify the activities and role of 'alternative tourism', the UNWTO replaced the term 'alternative tourism' with RT $[22,28]$ and all agreed on the definition of RT as "all forms of tourism which respect the host's natural, built, and cultural environments and the interest of all parties concerned" [22, p. 259]. Fennell [29] argues that 'alternative tourism' encompasses ethical, accountable, and responsible behaviour. According to the Cape Town Declaration (2002) RT is "an approach to the management of tourism aimed at maximising benefits (economic, social, and environmental) and minimizing costs to destination" [30]. Moreover, it involves local communities' participation in economic activities and decision making, enhancing local communities (environmentally, economically, and socially), making a contribution to conservation, offering access to everyone, and stimulates connection and respect between guests and hosts [31].

Blackstock et al. [28] argue that "RT focuses on the choices made by visitors and their hosts; emphasising behaviour in order to change tourism outcomes thus, RT provides a particular lens by which to consider how to improve the sustainability of tourism". Reid [32] says that RT emphasizes the capability of tourists to make differences throughout their activities directed by the values and principles of RT. Similarly, Hall and Brown [33] say, RT offers practical thought and judgement by tourists. Therefore, in the light of RT, a responsible tourist can be defined as a tourist who protects the environment (flora, fauna, landscapes), respects local cultures (tradition, religion, heritage), benefits local communities (economically and socially), conserves natural resources (water, energy) and minimizes pollution (noise, waste, congestion) [34, 20].

Worldwide, there are relatively very few studies available which tried to seek out ST and/or RT exclusively from the perspective of domestic tourists however, some of the recent studies are partly exceptions $[24,35,25,36]$. It is important to remember that some of the studies and facts outlined in this section are not focused completely on the domestic tourism market. But, attitudes, perceptions, and behaviours that different nationalities' tourists possess towards ST and/or RT practices do provide the sense and light to identify the variables that are useful to conduct the current study. So, it is fairly reasonable to include them in the literature and further consider them to point out appropriate attitude formation determinants for the anticipated research.

In 2002, English Tourism Council (ETC) conducted a study to find out attitudes of British tourists to the ST management [36]. Major findings of this study are-

TABLE I. TBL DETERMINANTS USED BY ETC (2002) TO SURVEY ON DOMESTIC TOURISM MARKET

\begin{tabular}{|l|c|}
\hline \multicolumn{1}{|c|}{ TBL attitude statements } & $\begin{array}{c}\text { Respondents } \\
\text { agreed or } \\
\text { favorably } \\
\text { replied (\%) }\end{array}$ \\
\hline $\begin{array}{l}\text { "Tourism should protect the traditional characteristics } \\
\text { of a destination" }\end{array}$ & $96 \%$ \\
\hline $\begin{array}{l}\text { "Well managed environment is the most important } \\
\text { factor whilst choosing holiday or short break } \\
\text { destination" }\end{array}$ & $63 \%$ \\
\hline $\begin{array}{l}\text { "Ready to pay extra to stay in establishments that are } \\
\text { committed with good environmental practices and } \\
\text { employ local staffs" }\end{array}$ & $65 \%$ \\
\hline $\begin{array}{l}\text { "While on holiday, it is important to eat local food and } \\
\text { drink local products" }\end{array}$ & $77 \%$ \\
\hline $\begin{array}{l}\text { "Local people should be directly benefited from } \\
\text { tourism" }\end{array}$ & $74 \%$ \\
\hline
\end{tabular}




\begin{tabular}{|l|c|}
\hline \multicolumn{1}{|c|}{ TBL attitude statements } & $\begin{array}{c}\text { Respondents } \\
\text { agreed or } \\
\text { favorably } \\
\text { replied (\%) }\end{array}$ \\
\hline $\begin{array}{l}\text { "Experiencing local traditions, festivals, other cultural } \\
\text { events key part of the holiday" }\end{array}$ & $65 \%$ \\
\hline $\begin{array}{l}\text { "While on Holiday, it is important not to damage the } \\
\text { environment" }\end{array}$ & $97 \%$ \\
\hline $\begin{array}{l}\text { "Willing to make a donation to upkeep the } \\
\text { environment and wild life conservation" }\end{array}$ & $63 \%$ \\
\hline \begin{tabular}{l} 
"Like to follow a visitor code of conduct" \\
\hline "Tourism should directly benefit local businesses"
\end{tabular} & $92 \%$ \\
\hline $\begin{array}{l}\text { "While on holiday, it is important to buy locally } \\
\text { produced goods" }\end{array}$ & $82 \%$ \\
\hline $\begin{array}{l}\text { "While on holiday, visitor should respect local } \\
\text { heritage and culture" }\end{array}$ & $93 \%$ \\
\hline "It is important to set limits on tourism development" \\
\hline $\begin{array}{l}\text { "Limits should be set on visitor numbers at } \\
\text { destination" }\end{array}$ & $63 \%$ \\
\hline $\begin{array}{l}\text { "Prepare to pay extra to stay with accommodation } \\
\text { produced goods" }\end{array}$ & $69 \%$ \\
\hline $\begin{array}{l}\text { Source: Dinan [36] (compiled by author) } \\
63 \%\end{array}$ \\
\hline
\end{tabular}

Later, many scholars in their studies on ST and/or RT from domestic or international tourists' perspective covered the above mentioned TBL issues along with other context specific determinants $[37,24,35,38,25,39]$. Therefore, for the intended research, the TBL determinants of these studies have been considered to outline key variables and further relevant variables have been used to develop the survey questionnaire and to measure the attitudes of domestic tourists of Bangladesh towards RTM.

Martin [40] in his study on British tourists found that, most of the British tourists think it is fairly or very important that their holidays don't damage the environment (over 87\%), have the opportunity to experience the local culture (79\%), and can positively contribute to benefit the local community $(72 \%)$. Moreover, $76 \%$ of British tourists felt that, it is important that their trip benefit the people living at their destination [41] and $45 \%$ of British tourists are willing to pay more for their trip if they are assured that part of their money will be used to preserve the local environment and to minimize the harmful environmental effects of tourism [42]. In the U.S.A, $49 \%$ of travellers prefer to stay with small-scale accommodations that are run by local people [43]; more than $75 \%$ of travellers believed "it is important that their visits don't harm the environment" [20, p. 229]; $66 \%$ of the mature population are engaged with environmentally responsible travel, and $61 \%$ of travellers believed "experience is better when their destination preserves its natural, historic and cultural sites" [43].

Study found that $90 \%$ of British, $65 \%$ of American, and $63 \%$ of Australian tourists believed at a destination, it is part of hotels' and other tourism businesses' responsibility to actively defend and support the environment and local communities including investing in local schools and hospitals. In addition, at a domestic market level, $65 \%$ of British and Australians and 26\% of Americans demanded that hotels and other tourism businesses need to engage in good environmental practices (reducing waste, natural resource use and energy consumption) along with supporting local communities' environmental and social causes [44]. The same study found that $71 \%$ of British and Australians and $53 \%$ of Americans like to see that tourism at a destination protects the culture and heritage of local communities and supports their well-being. Moreover, $74 \%$ of British, $62 \%$ of Australians and $57 \%$ of U.S travellers prefer those hotels who seek to employ staffs from the local communities [44]. In Australia's domestic tourism market, more than $60 \%$ of tourists and travellers are conscious about the negative impacts and threats of tourism on the environment [45].

Dann [46] argues that tourists may have the same nationality but they are different in terms of their personality and character. Similarly, Weiermeir [47] says, within a country, tourists travel for different reasons and have different set of motivations to travel. Moreover, he argues that at a destination, native tourists are different from each other due to their differences in socio-demographic and travel characteristics [47]. So, DMOs need to recognize and catch the attention of right type of tourists to ensure the long term sustainability of their destination [24]. Furthermore, Kang and Moscardo [25] justify that, in spite of having the same nationality, responsible tourist behaviour significantly varies in terms of age, gender, occupation, and income level of the tourist. On the other hand, Dodds et al. [21] state that along with the age, gender, occupation, and income, tourists' level of education is a significant influential factor that positively influences their behaviour to act in a more responsible way (economically, socially, and environmentally).

\section{RESEARCH QUESTION AND HYPOTHESES}

Considering the aim and objectives of the current research and based on the earlier discussion, following research questions and hypotheses have been set for the current study.

RQ1: How are domestic tourists' attitudes towards RTM at CB formed?

$\mathrm{H}_{1 \_1}$ : Attitude to RTM are the function of social, economic, environmental responsibility and sociodemographic characteristics of domestic tourist.

RQ2: Does each of the TBL components have equal influence on forming domestic tourists' attitudes towards RTM?

$\mathrm{H}_{1 \_2}$ : Each of the TBL components has different levels of influence on forming domestic tourists' attitudes towards RTM

RQ3: Do domestic tourists' attitudes to RTM differ according to socio-demographic variables?

$\mathrm{H}_{1 \_3}$ : Domestic Tourists' attitudes towards RTM varies due to differences in their socio-demographic characteristics.

\section{METHODOLOGY}

The present study started by applying a direct approach of exploratory research design, where, one major non-disguised method (in-depth interview) has been used to collect primary data at the initial level [48]. Therefore, at the initial phase of 
the research, in-depth interviews on 6 ST experts of Bangladesh have been conducted by the researcher (author) to gain more insights and understanding about RTM and its TBL components under the context of Bangladesh and the case study site, CB. Moreover, The UNWTO [49] in their technical manual on domestic tourism statistics mentioned that, visitor survey at tourist site is better suited for the estimation of domestic tourists, their characteristics, and to estimate their attitude and opinion on specific issues [49, p. 26]. Similarly, Cooper et al. [1] said that one of the more effective methods used to study domestic tourists is the visitor survey, which can be conducted at popular tourist destinations or in areas where high levels of tourists' activities are visible. Moreover, they state that information gained through the visitor survey on the domestic market at a specific site leads to an estimated volume and value of tourism to the destination, profiling tourists and their visits, and eliciting opinions about the destination and associated attitudes [1]. Therefore, following the exploratory research phase, a descriptive research design (survey methods) has been used to collect primary data (through the questionnaire) from the target respondents (domestic tourists of Bangladesh) at the case study site (CB).

Since there is no accurate reliable information available about the population size of the domestic tourists in $\mathrm{CB}$, 'Five steps process' has been followed to determine the probabilistic sample size of an infinite population $[50,48]$ and based on the calculation the sample size was fixed as 385 for data collection. To ensure every respondent in the population had the equal chance to be selected as a sample, and to ensure population representative sample, probabilistic Stratified Random Sampling (SRS) has been used as the sampling technique.

A mixed methodology approach recommended by many scholars [50, 51] has been used to develop the survey instrument for this study. The survey questionnaire was divided into three parts. The first part covered the questions regarding socio-demographic characteristics of domestic tourists. The second section of the questionnaire was designed to get detailed information about the attitudes of the respondents towards each TBL component of RTM. Therefore, this section covered 27 questions about cognitive and affective states of mind regarding TBL components (economic, social, and environmental) of RTM. A five point Likert scale $(2=$ Disagree, $3=$ Somewhat Disagree, $4=$ Neutral, $5=$ Somewhat Agree, and $6=$ Agree) with one don't know option $(1=$ Don't Know) was used in this section to collect the attitudinal data. The final section of the questionnaire covered the questions relating to the future intention and expectations of domestic tourists. This section included information about how much tourist would like to pay to help fund initiatives for environmental protection and social welfare at $\mathrm{CB}$, and what they would like to see as a result of their fund contribution. Structured (close-ended) questions have been used to collect the data from the 385 respondents.

Descriptive statistics - frequency distribution and cross tabulation analysis have been used to profile the domestic tourists on the basis of their socio-demographic characteristics and to find out tourists' future intention and expectations.
Further, multivariate dependence data analysis technique multiple regression analysis has been used to test the hypotheses and to find out the level of influence of each TBL component and the socio-demographic variables that altogether form domestic tourists' attitudes towards RTM.

\section{Proposed Conceptual Model}

Considering the objectives, research questions, and hypotheses of the current research, the following conceptual model (Fig. 1) has been developed to measure the attitudes of domestic tourists towards RTM at CB.

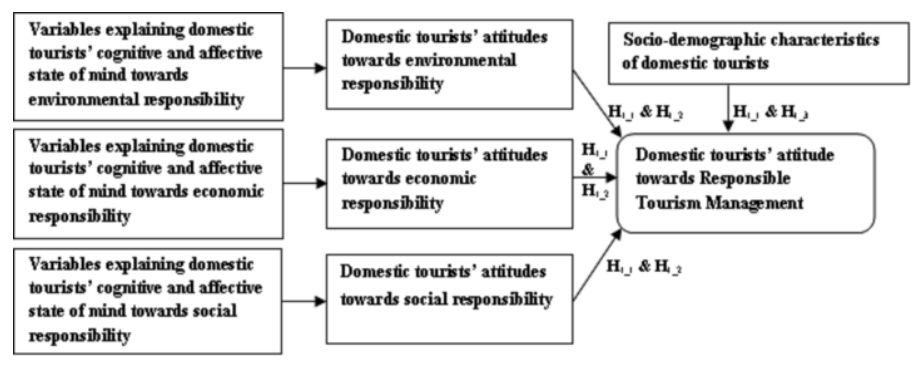

Fig. 1. Proposed conceptual model for domestic tourists' attitudes measurement towards RTM

According to the proposed conceptual model, the estimation of the current attitudinal level of domestic tourists towards each TBL component has been measured with the help of the identified respective cognitive and affective variables. The cognitive element of each TBL component covered a domestic tourist's mental images, his/her understanding, perception, and interpretations about the considered issue or object. The affective element of each TBL component covered the feelings or emotions a domestic tourist had about the observed issue or object. Furthermore, the sociodemographic characteristics of domestic tourists were incorporated in to the model as they were highlighted as potential significant influential variables which form and influence the attitudinal level of a tourist. Therefore, combined, they reflected the mindset of a domestic tourist towards RTM.

Moreover, to address the aforesaid proposed graphical and verbal analytical models, following multiple regression model has been developed to measure the relative influence of each independent variable (TBL components and sociodemographic characteristics) on the dependent variable (Attitudes towards RTM).

$$
\begin{gathered}
Y=\beta_{0}+\beta_{1} X_{1}+\beta_{2} X_{2}+\beta_{3} X_{3}+\beta_{4} X_{4}+\beta_{5} X_{5}+\beta_{6} X_{6}+\beta_{7} X_{7}+ \\
\beta_{8} X_{8}+\beta_{9} X_{9}+\beta_{10} X_{10}+e_{i}
\end{gathered}
$$

Here,

$\mathrm{Y}=$ Domestic tourists' attitudes towards RTM, $\beta_{0}=$ Constant, $\beta_{1}, 2, \quad 3, \ldots, 10=$ Coefficients associated with independent variables, $\mathrm{X}_{1}=$ Gender, $\mathrm{X}_{2}=$ Age, $\mathrm{X}_{3}=$ Marital status, $\mathrm{X}_{4}=$ Occupation, $\mathrm{X}_{5}=$ Education, $\mathrm{X}_{6}=$ Monthly average income, $\mathrm{X}_{7}=$ Residential area, $\mathrm{X}_{8}=$ Attitude towards environmental responsibility, $\mathrm{X}_{9}=$ Attitude towards economical 
responsibility, $\mathrm{X}_{10}=$ Attitude towards social responsibility, $\mathrm{e}_{\mathrm{i}}$ $=$ Error.

\section{RESUlts AND HyPOTHESES TESTING}

Following tables (Table II, III, and IV) are the statistical output of the aforementioned regression model -

TABLE II. MODEL SUMMARY OF DOMESTIC TOURISTS’ ATTITUDES TOWARDS RTM

\begin{tabular}{|c|c|c|c|c|}
\hline \multicolumn{5}{|c|}{ Model Summary } \\
\hline Model & $\boldsymbol{R}$ & $\boldsymbol{R}^{\mathbf{2}}$ & $\begin{array}{c}\text { Adjusted } \\
\boldsymbol{R}^{2}\end{array}$ & $\begin{array}{c}\text { Std. error of the } \\
\text { estimate }\end{array}$ \\
\hline 1 & 0.774 & 0.625 & 0.604 & 0.399 \\
\hline
\end{tabular}

Here, the value of $\mathrm{R}$ is 0.774 which means there is significant positive relationship existing among dependent (Attitudes towards RTM) and independent variables (eenvironmental, eeconomic, ssocial responsibilities and socio-demographic variables). So, we can conclude that domestic tourists' attitudes towards RTM is highly correlated with the identified independent variables. Moreover, here, the value of $\mathrm{R}^{2}=0.625$ means that $62.5 \%$ of domestic tourists' attitudes towards RTM is explained by the identified environmental, economic, social responsibilities and sociodemographic predictors. Therefore, both the value of $\mathrm{R}$ and $\mathrm{R}^{2}$ support the rejection of the null hypothesis of the first research question (RQ1) thus, we can accept the $\mathrm{H}_{1_{-}}$.

TABLE III. ANOVA OUTPUT OF THE REGRESSION MODEL OF ATTITUDES MEASUREMENT TOWARDS RTM

\begin{tabular}{|c|l|c|c|c|c|c|}
\hline \multicolumn{7}{|c|}{ ANOVA $^{\mathbf{2}}$} \\
\hline \multirow{2}{*}{ Model } & $\begin{array}{c}\text { Sum of } \\
\text { Square }\end{array}$ & Df & $\begin{array}{c}\text { Mean } \\
\text { Square }\end{array}$ & $\boldsymbol{F}$ & Sig. \\
\cline { 2 - 7 } 1 & Regression & 463.291 & 10 & 19.818 & 41.831 & 0.000 \\
\cline { 2 - 7 } & Residual & 119.794 & 375 & 0.499 & & \\
\cline { 2 - 7 } & Total & 583.085 & 385 & & & \\
\hline
\end{tabular}

Table III depicts that, the regression model to measure the attitudes of domestic tourists towards RTM is significant at $\alpha$ $=0.05$. On the other hand, the following table (Table IV) represents the coefficients output of the regression model.

TABLE IV. COEFFICIENTS OUTPUT OF THE REGRESSION MODEL OF DOMESTIC TOURISTS' ATTITUDES TOWARDS RTM

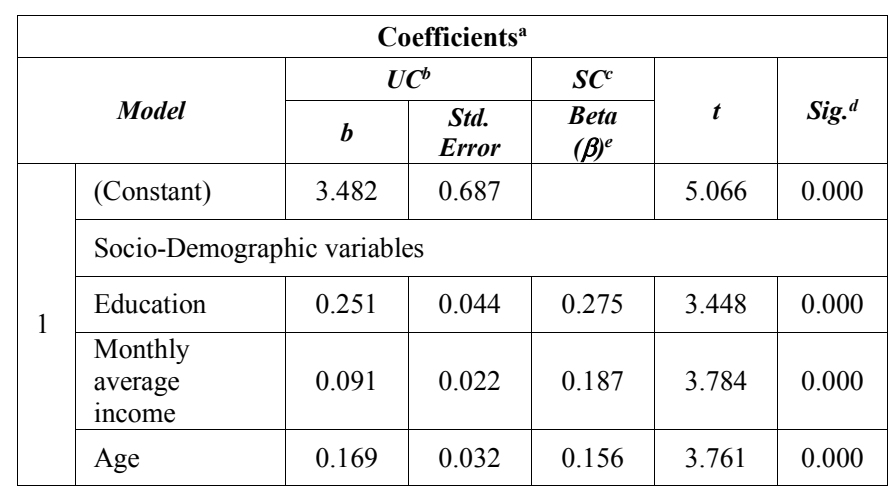

\begin{tabular}{|c|c|c|c|c|c|}
\hline \multicolumn{6}{|c|}{ Coefficients $^{\mathrm{a}}$} \\
\hline \multirow[b]{2}{*}{ Model } & \multicolumn{2}{|c|}{$U C^{b}$} & \multirow{2}{*}{$\begin{array}{c}S C^{c} \\
\text { Beta } \\
(\beta)^{e}\end{array}$} & \multirow[b]{2}{*}{$t$} & \multirow[b]{2}{*}{ Sig. ${ }^{d}$} \\
\hline & $\boldsymbol{b}$ & $\begin{array}{c}\text { Std. } \\
\text { Error }\end{array}$ & & & \\
\hline Occupation & 0.100 & 0.037 & 0.123 & 2.677 & 0.008 \\
\hline Gender & -0.062 & 0.033 & -0.111 & -1.861 & 0.64 \\
\hline $\begin{array}{l}\text { Residential } \\
\text { area }\end{array}$ & -0.011 & 0.009 & -0.071 & -1.272 & 0.204 \\
\hline Marital status & -0.096 & 0.104 & -0.052 & -0.916 & 0.360 \\
\hline \multicolumn{6}{|c|}{ Attitudes formation TBL components } \\
\hline $\begin{array}{l}\text { Environmental } \\
\text { responsibility }\end{array}$ & 0.940 & 0.115 & 0.401 & 8.203 & 0.000 \\
\hline $\begin{array}{l}\text { Economic } \\
\text { responsibility }\end{array}$ & 0.837 & 0.141 & 0.336 & 5.939 & 0.000 \\
\hline $\begin{array}{l}\text { Social } \\
\text { responsibility }\end{array}$ & 0.278 & 0.079 & 0.196 & 3.521 & 0.000 \\
\hline \multicolumn{6}{|c|}{ a. Dependent variable: Attitudes towards RTN } \\
\hline \multicolumn{6}{|c|}{ b. Unstandardized Coefficient: } \\
\hline & & & \multicolumn{3}{|c|}{ c. Standardized Coefficier } \\
\hline & & & & \multicolumn{2}{|c|}{ d. Significant at $\alpha=0$. } \\
\hline
\end{tabular}

For the developed regression model, $\beta$ 's value associated with each of the independent variables (including sociodemographic variables) is not zero. This supports to reject the null hypotheses of the second research question (RQ2) thus, can accept $H_{1} 2$. Moreover, $\beta s^{\prime}$ values associated for the each of the socio-demographic variables is not zero either, this finally supports to reject the null hypothesis of the third research question (RQ3) consequently, can accept $\mathrm{H}_{13}$. Therefore, by consolidating the findings of the regression model, it can be concluded that, the null hypotheses of the outlined three research questions (RQ1 - RQ3) can be rejected, allowing to accept the respective alternative hypotheses. $\left(\mathrm{H}_{1 \_1}-\mathrm{H}_{1 \_} 3\right)$.

The following table (Table V) describes domestic tourists' intentions to help fund initiatives for environmental protection and social welfare at $\mathrm{CB}$ :

TABLE V. DOMESTIC TOURISTS' INTENTION TO PAY TO HELP FUND INITIATIVE FOR ENVIRONMENTAL PROTECTION AND SOCIAL WELFARE

\begin{tabular}{|c|c|c|c|}
\hline $\begin{array}{c}\text { Contribution } \\
\text { (BDT) }\end{array}$ & Frequency & Percent & $\begin{array}{c}\text { Cumulative } \\
\text { Percentage }\end{array}$ \\
\hline $\begin{array}{c}\text { Don't want to } \\
\text { contribute }\end{array}$ & 68 & 17.7 & 17.7 \\
\hline Less than 50 & 66 & 17.1 & 34.8 \\
\hline $51-100$ & 77 & 20.0 & 54.8 \\
\hline $100-200$ & 56 & 14.5 & 69.4 \\
\hline $201-300$ & 24 & 6.2 & 75.6 \\
\hline $301-400$ & 11 & 2.9 & 78.4 \\
\hline $401-500$ & 14 & 3.6 & 82.1 \\
\hline More than 500 & 69 & 17.9 & 100.0 \\
\hline Total & 385 & 100.0 & \\
\hline
\end{tabular}

Next table (Table VI) explains what domestic tourists would like to see as a result of their fund contribution. 
TABLE VI. DOMESTIC TOURISTS' FUTURE EXPECTATION TO SEE AS A RESULT OF THEIR FUND CONTRIBUTION

\begin{tabular}{|l|c|c|}
\hline \multicolumn{1}{|c|}{$\begin{array}{c}\text { Domestic tourists want to see as a } \\
\text { result of their fund contribution }\end{array}$} & Frequency & Percent \\
\hline $\begin{array}{l}\text { Environmental protection and } \\
\text { development }\end{array}$ & 237 & $61.6 \%$ \\
\hline Safety and security & 150 & $38.9 \%$ \\
\hline Marine life protection and development & 87 & $22.5 \%$ \\
\hline Wild life conservation & 83 & $21.5 \%$ \\
\hline Social welfare of the local community & 51 & $13.2 \%$ \\
\hline Education & 46 & $11.9 \%$ \\
\hline $\begin{array}{l}\text { Local community's development } \\
\text { (economic, infrastructure, standard of } \\
\text { living etc.) }\end{array}$ & 34 & $8.8 \%$ \\
\hline Don't know & 35 & $9.1 \%$ \\
\hline Others & 06 & $1.5 \%$ \\
\hline
\end{tabular}

\section{DISCUSSION}

In some cases the present study found different results compared with earlier studies. Major reason behind the dissimilarity might be the difference in sample respondents of current study with the earlier studies. For example in Dinan's [36] study, sample respondents were British tourists who are comparatively more aware about the negative impacts of tourism on the local environment, economy, society, and culture. In Kang and Moscardo's [25] study, British, Australian, and Korean tourists were the participants. Though Australian and Korean tourists in those study were domestic tourists, they had experiences of travelling abroad. In Deng and Bender's [35] study, sample respondents were both domestic (West Virginia, USA) and international. Being citizen of a developed country, visitors of the West Virginia were more aware about tourism and its impact on their environment, economy, and society. On the other hand, in Dodds et al. [21], Chafe [39], CREST [43], IHEI [44], MORI [52], and Martin's [40] studies, sample respondents were international tourists and they were mostly from developed countries. Spenceley [20] and Budeanu [38] argue that tourists of developed countries are more aware about ST and RT, their positive practices, and are more responsible tourists compared with tourists from other parts of the world. Due to the differences exist in the socio-economic and cultural background of the sample respondents of the present study with the sample respondents of the aforesaid earlier studies, it is fairly logical to conclude that their attitudes towards RTM will vary.

In contrast with Deng and Bender [35] findings, the present study found that age, education, monthly average income, and occupation are the significant influential sociodemographic variables and have respectively $27.5 \%, 18.7 \%$, $15.6 \%$, and $12.3 \%$ of influence when shaping tourists' attitudes towards RTM (see Table IV). Moreover, these variables are positively correlated with attitude formation, which means that domestic tourists with more education, higher level of income, and older have a more positive attitude towards RTM, supporting Daud and Rahman [24], and Budeanu's [38] findings. However, the findings of this study partly refute Kang and Moscardo [25] and Dodds et al.'s [21] findings who found that gender and marital status influence tourists' attitudes to RT, which is not the case for $\mathrm{CB}$, Bangladesh. Moreover, similar to Buswell [53] arguments and in contrast with Debbage's [54] findings, the present study found that residential area of the Bangladeshi tourists had no influence on their attitudes formation towards RTM.

Along with the socio-demographic variables, tourists' attitudes towards RTM is formed by environmental, economic, and social responsibilities. The level of influence of environmental, economic, and social responsibilities on attitude formation is $40.1 \%, 33.6 \%$, and $19.6 \%$ respectively (see Table IV). Moreover, these predictors are positively correlated with attitude formation towards RTM means, tourists with more positive attitudes towards environmental, economic, and social responsibility have more positive attitudes towards RTM. Tosun [55] and Ratz [56] have argued that in developing and LDCs, economic sustainability is more valued by the tourists and other stakeholders than environmental and socio-cultural sustainability, which is not the case for $\mathrm{CB}$, Bangladesh. Moreover, in contrast with Budeanu [38] arguments and Dodds et al. [21], Deng and Bender's [35] findings, the present study found that the domestic tourists of Bangladesh are more concerned and have more positive attitudes towards environmental and economic responsibilities than social responsibility. Similar to Gezici's [57] findings, the present study found that tourists consider environmental responsibility more significant than economic and social responsibilities. This is consistent with research in other Asian countries, such as Korea [25], Japan [58], and China [59]. In all these cases, residents from these countries scored high on environmental concern and conservation attitudes.

Tables V and VI represent the future intention and expectations of the respondents. Although respondents showed favourable attitudes towards each TBL component and to RT management, it is important to determine whether they are willing to take any level of responsibility by themselves and how their tourism experiences at CB can be improved. Though willingness to pay may differ from actual behaviour, the findings on this question are still helpful and will provide a useful indication for future research. Therefore, respondents were first asked about how much they would like to pay to help fund initiatives for environmental protection and social welfare of $\mathrm{CB}$, and then they were asked what measures they would like to see implemented because of their contribution.

Although some authors [60,61, 62, 63] have outlined problems with tourists' taxes, this didn't appear for the case in CB. In contrast with Budeanu's [38] findings, the present study found that $82.3 \%$ of the respondents were willing to pay to help fund initiatives for the environmental protection and social welfare of CB (see Table V), supporting Dodds et al.'s [21] findings. However, among the respondents who stated their willingness to pay for environmental protection and social welfare, $51.6 \%$ were willing to pay only up to BDT 200 (about 2.5 USD). Although, the data concerns only stated willingness and the amount is still very low, considering the volume of the domestic tourists at $\mathrm{CB}$, the DMOs still may consider this as a potential funding source in future planning 
and development. Moreover, this fund can be implemented to ensure the sustainability practices at $\mathrm{CB}$.

Furthermore, this section tried to explore what sustainability measures respondents want to see as a result of their fund contribution. Similar to Gezici [57], Franzen [58], Chan's [59] findings, the present study found that respondents are most concerned about environmental attributes and their protection and development. The top four sustainability measures that respondents indicated were environmental protection and development, more safety and security, marine life protection, and wild life conservation $(61.6 \%, 38.9 \%$, $22.5 \%$, and $21.5 \%$ respectively) (see Table VI). On the contrary, very few respondents want to see their fund contribution go to social welfare and education of the local community, and the local community's development $(13.2 \%$, $11.9 \%$, and $8.8 \%$ respectively) (see Table VI). Therefore it is fairly logical to draw the proposition that respondents are more concerned and want to see more improvement on environmental attributes than in the social attributes of the destination's (CB's) sustainability, also supporting the present study's earlier findings. Therefore, to improve tourists' overall attitudes to RT management, the DMOs need to work more on improving tourists' attitudes on social sustainability than the other two components of TBL.

\section{CONCLUSION}

The aim of this research was to find out domestic tourists' attitudes towards RTM at CB, Bangladesh. The research also aimed to find out whether domestic tourists' attitudes vary in terms of socio-demographic variables in order to identify the most appropriate target market for maximising the positive impacts of domestic tourism whilst minimising the negative ones. The aforementioned findings suggest that domestic tourists have positive attitudes towards each TBL component and to RTM. Further, this study suggests to include tourists' socio-demographic characteristics whilst measuring their attitudes, as their attitudes significantly vary due to variation in their socio-demographic characteristics. To ensure the sustainability of each TBL component and of RTM, the findings of the present study suggests that for $\mathrm{CB}$, the best approach to segment and target the domestic tourism market is based on age, education, income, and occupation. Like Dolnicar et al's. [64] findings, this study recommends that within the context of $\mathrm{CB}$, Bangladesh tourists who are more educated, have higher level of income, and are of mid age to older are not only environmentally friendly tourists but also economically and socially responsible tourists.

The first objective of this research was to measure the influence of each TBL component (social, economic, and environmental) on the domestic tourists' attitudes formation towards RTM. The findings of the present study suggest that all TBL components are positively correlated to formulate tourists' attitudes towards RTM. In contrast with Dodds et al. [21], Budeanu [38], and Deng and Bender's [35] findings, the present study found that tourists have more positive attitudes towards environmental and economical responsibilities than social responsibility. Moreover, similar with other Asian countries (Korea, Japan, China), this study found that tourists consider environmental attributes and responsibility as more significant than the other two components of the TBL.

The second objective of this research was to draw conclusions and formulate recommendations about which component(s) of the TBL should be considered by DMOs to improve tourists' positive attitudes towards RT development at $\mathrm{CB}$, Bangladesh. The findings of the present study support that though tourists have positive attitudes to each of the TBL components and to RTM, still there is scope to improve their attitudes. Moreover, to improve tourists' overall attitudes towards RT this study suggests that the DMOs need to work more on attaining social responsibility than other two components of TBL as tourists have more favourable attitudes towards environmental and economic responsibility than the social responsibility.

Based on the growth of tourism and its impacts, there is a need to consider how CB can be preserved and managed by addressing environmental, economic, and social issues. Applying sustainability measures to tourism in $\mathrm{CB}$ can be potentially less harmful than continuing to build and develop in an unchecked manner. Ma and Hassink [65] outlined that destinations will need to maintain their natural aesthetic appeal to maintain their tourism numbers. This study found that the tourists as a key stakeholder in the tourism model cares about the sustainability of the $\mathrm{CB}$ and appears to be willing to pay to protect its environmental and social fabric. Moreover, they would like to see sustainability practices at CB particularly on the environmental component of RTM as a result of their fund contribution. The present study suggests that the tourist is a key stakeholder and should be considered when destinations develop their tourism amenities.

In summary, the findings of this study have made an important contribution to existing literature and have highlighted some important market implications. This study will assist the DMOs to profile and define the domestic tourism market of $\mathrm{CB}$ more precisely, which was almost missing in the earlier literature. Moreover, the findings on the domestic tourists' mindset towards RTM is unique as this has been highlighted within the existing literature on RTM and on the domestic tourism market of Bangladesh for the first time. With the support of and reference to the present study, the DMOs can work on each of the TBL components to enhance the positive attitudes of tourists towards RT practices at CB. Moreover, they can use the same framework to study similar subject areas at other destinations of Bangladesh. The present study also contributes to the RT literature as, worldwide very few studies tried to find out about the attitudes towards RT development and/or management particularly from tourists' perspective $[22,25,66]$. Furthermore, it is largely ignored when researching in developing countries. Therefore, the present study on Bangladesh also minimizes the identified literature gap for developing countries.

\section{REFERENCES}

[1] C. Cooper, J. Fletcher, A. Fyall, D. Gilbert, and S. Wanhill, Tourism: Principles and practice, 4th ed. Harlow, England: Prentice Hall Financial Times, 2008 
[2] International Labour Organization, Toolkit on poverty reduction through tourism, $2^{\text {nd }}$ ed. Geneva: ILO, 2013.

[3] V. T. C. Middleton, A. Fyall, M. Morgan, and A. Ranchhod, Marketing in travel and tourism, 4th ed. Amsterdam: Butterworth-Heinemann, 2009.

[4] E. Eijgelaar, P. Peeters, and P. Piket, "Domestic and International Tourism in a Globalized World," in Ever the twain shall meet - relating international and domestic tourism, Rajasthan, India, RC50 International Tourism, International Sociological Association Jaipur, 2008, Nov, 24-26, pp. 1-26.

[5] K. B. Ghimire, "The growth of national and regional tourism in developing countries: an overview," in The Native Tourist - Mass Tourism within Developing Countries, K. B. Ghimire, Ed. London: Earthscan.

[6] J. Mazimhaka, "Diversifying Rwanda's tourism industry: A role for domestic tourism," Development Southern Africa, vol. 24, no. 3, pp. 491-504, Sep. 2007.

[7] Economic and Social Commission for Asia and the Pacific, "Regional Study on the Role of Tourism in Socio-Economic Development," United Nations Economic and Social Council, Almaty, Kazakhstan, Tech. Rep. DMR: A2007-000079 260307, May17-23, 2007.

[8] World Travel \& Tourism Council, "Travel \& Tourism Economic Impact 2016 Asia Pacific," World Travel \& Tourism Council, London, UK, sec. Economic Research, pp. 1-13, 2016. [Online]. Available: http://www.wttc.org/-

/media/files/reports/economic\%20impact\%20research/regions\%202016/ asiapacific2016.pdf. Accessed: Mar. 22, 2016.

[9] World Travel \& Tourism Council, "Travel \& Tourism Economic Impact 2016 South Asia," World Travel \& Tourism Council, London, UK, sec. Economic Research, pp. 1-17, 2016. [Online]. Available: http://www.wttc.org/-

/media/files/reports/economic\%20impact\%20research/regions\%202016/ southasia2016.pdf. Accessed: Mar. 22, 2016.

[10] R. Scheyvens, Tourism for development: Empowering communities. United States: Prentice Hall Professional Technical Reference, 2002.

[11] P. U. C. Dieke, The political economy of tourism development in Africa (tourism dynamics). New York: Cognizant Communication Corp., 2000.

[12] D. L. Gladstone, From pilgrimage to package tour: Travel and tourism in the Third world. London: Routledge, 2006.

[13] M. R. Amin, "Domestic Tourists' Attitude towards Responsible Tourism Development: A Case Study on Cox's Bazar, Bangladesh," MSc. thesis, School of Events, Tourism \& Hospitality, Leeds Beckett University, Leeds, Yorkshire, 2014.

[14] United Nation World Tourism Organization, "Destination Report - The People's Republic of Bangladesh," in Asia-Pacific Newsletter 2015, C. Kim, Ed., no. 41, Madrid, Spain: United Nation World Tourism Organization, 2015, pp. 1-57.

[15] Bangladesh Parjatan Corporation. (2014, Nov. 24). Cox's Bazar Sea Beach. [Online]. Available: http://www.parjatan.portal.gov.bd/site/page/6ee6072e-bf5b-4078-82d9df007e92e93b/Cox's-Bazar. Accessed: Mar. 20, 2016.

[16] A. Ethirajan. (2012, Dec. 26). Bangladesh's Cox's Bazar: A paradise being lost?. (BBC News, sec. Asia) [Online]. Available: http://www.bbc.com/news/world-asia-19340259. Accessed: Mar. 04, 2016.

[17] M. Rahman, "Exploring the Socio-Economic Impacts of Tourism: A Study of Cox's Bazar, Bangladesh," Ph.D thesis, Cardiff School of Management, UWIC, Cardiff, UK, 2010.

[18] A. Hossain, "Marketing Strategies of Tourism Business in Bangladesh," Dhaka University Journal of Business Studies, vol. 25, no. 1, pp. 73-98, June 2005.

[19] K. W. Tuhin and T. H. Majumder, "An Appraisal of Tourism Industry Development in Bangladesh," European Journal of Business and Management, vol. 3, no. 3, pp. 287-298, 2011. [Online]. Available: http://www.iiste.org/Journals/index.php/EJBM/article/view/284. Accessed: Mar. 04, 2016.

[20] A. Spenceley, Ed., Responsible tourism: Critical issues for conservation and development. London: Earthscan Publications, 2008.
[21] R. Dodds, S. R. Graci, and M. Holmes, "Does the tourist care? A comparison of tourists in Koh Phi Phi, Thailand and Gili Trawangan, Indonesia," Journal of Sustainable Tourism, vol. 18, no. 2, pp. 207-222, Mar. 2010.

[22] D. Stanford, "'Exceptional visitors': Dimensions of tourist responsibility in the context of New Zealand," Journal of Sustainable Tourism, vol. 16, no. 3, p. 258-275, Dec. 2008.

[23] E. T. Byrd, "Stakeholders in sustainable tourism development and their roles: Applying stakeholder theory to sustainable tourism development," Tourism Review, vol. 62, no. 2, pp. 6-13, May 2007.

[24] N. Daud and S. A. Rahman, "Tourist Attitudes towards Sustainable Tourism: Empirical Evidence From Malaysian National Park, Taman Negara," International Proceedings of Economics Development \& Research, vol. 3, pp. 254-258, 2011. [Online]. Available: http://www.ipedr.com/vol3/52-M10023.pdf. Accessed: Mar. 02, 2016.

[25] M. Kang and G. Moscardo, "Exploring cross-cultural differences in attitudes towards responsible tourist behaviour: A comparison of Korean, British and Australian tourists," Asia Pacific Journal of Tourism Research, vol. 11, no. 4, pp. 303-320, Dec. 2006.

[26] United Nation World Tourism Organization, Domestic Tourism in Asia and the Pacific. Madrid, Spain: United Nation World Tourism Organization, 2013.

[27] G. Miller and L. Twining-Ward, Monitoring for a sustainable tourism transition: The challenge of developing and using indicators, 1 st ed. Cambridge, MA, USA: CAB International North America, 2005.

[28] K. L. Blackstock, V. White, G. McCrum, A. Scott, and C. Hunter, "Measuring responsibility: An appraisal of a Scottish national park's sustainable tourism indicators," Journal of Sustainable Tourism, vol. 16, no. 3, p. 276 , Dec. 2008

[29] D. A. Fennell, Tourism ethics. Buffalo, NY: Channel View Publications, 2006.

[30] City of Cape Town, "Responsible tourism," 2016. [Online]. Available: http://www.capetown.gov.za/EN/TOURISM/Pages/ResponsibleTourism .aspx. Accessed: Mar. 10, 2016.

[31] Responsible Tourism Partnership, "What is Responsible Tourism?," 2016. [Online]. Available: http://responsibletourismpartnership.org/what-is-responsible-tourism/. Accessed: Mar. 12, 2016.

[32] D. G. Reid, Tourism, globalization and development: Responsible tourism planning, 1st ed. United Kingdom: Pluto Press, 2003.

[33] D. Hall and F. Brown, Tourism and welfare: Ethics, responsibility and sustainable well-being. United Kingdom: CAB International North America, 2006.

[34] H. Goodwin, Taking responsibility for tourism: Responsible tourism management. Woodeaton, Oxford: Goodfellow Publishers, 2011.

[35] J. Deng and M. Y. Bender, "Visitors' perceptions of tourism development in West Virginia", in Proceedings of the 2007 northeastern recreation research symposium, Bolton Landing, NY, Gen. Tech. Rep. NRS-P-23 , Department of Agriculture, Forest Service, Northern Research Station, 2007, pp. 181 - 188.

[36] C. Dinan, "The future is green: visitor attitudes towards sustainable tourism management," British Tourist Authority, pp. D-37- D41, May, 2003.

[37] T. Kline, "'Responsible Tourism in Samoa: An exploration of Attitudes in Samoa Towards Responsibility in Tourism," in Independent Study Project (ISP) Collection, Paper 1293, 2012. [Online]. Available: http://digitalcollections.sit.edu/isp_collection/1283. Accessed: Mar. 03, 2016.

[38] A. Budeanu, "Sustainable tourist behaviour? A discussion of opportunities for change," International Journal of Consumer Studies, vol. 31, no. 5, pp. 499-508, Sep. 2007.

[39] Chafe, "Consumer Demand and Operator Support for Socially and Environmentally Responsible Tourism," CSED and TIES, Washington, DC, USA, no. 104, Honey, M. Ed., April. 2005. [Online]. Available: $\mathrm{http}: / /$ www.rainforest-

alliance.org/branding/documents/consumer_demand.pdf. Accessed: Mar. 03, 2016. 
[40] MORI, "The British abroad - the changing world and its impact on Britain and the travel industry," 2002. [Online]. Available: https://www.ipsos-

mori.com/researchpublications/researcharchive/950/The-British-Abroad8212-The-Changing-World-And-Its-Impact-On-Britain-And-The-

Travel-Industry.aspx. Accessed: Mar. 02, 2016.

[41] H. Goodwin and J. Francis, "Ethical and responsible tourism: Consumer trends in the UK," Journal of Vacation Marketing, vol. 9, no. 3, pp. 271284, Jul. 2003.

[42] H. Goodwin, "Responsible Tourism and the Market," 2001. [Online]. Available:

http://www.haroldgoodwin.info/resources/Responsible\%20Tourism\%20 and\%20the\%20Market.pdf. Accessed: Mar. 02, 2016.

[43] Center for Responsible Travel, "Responsible Travel: U.S. Trends \& Statistics," Center for Responsible Travel (CREST), Washington, DC, USA, $2005 . \quad$ [Online]. Available: http://www.responsibletravel.org/news/Fact_sheets/Fact_Sheet_US Ecotourism.pdf. Accessed: Mar. 03, 2016.

[44] International Hotels Environment Initiative (IHEI), "Consumer attitudes towards the role of hotels in environmental sustainability," IHEI, July, 2002. [Online]. Available: http://www.hotelonline.com/News/PR2002_3rd/Jul02_IHEI.html. Accessed: Mar. 04, 2016.

[45] M. Hillery, B. Nancarrow, G. Griffin, and G. Syme, "Tourist perception of environmental impact," Annals of Tourism Research, vol. 28, no. 4, pp. 853-867, Jan. 2001

[46] G. Dann, "Limitation in the use of 'nationality' and 'country of residence' variables," in Tourism research: Critiques and challenges, D. Pearce and R. Butler, Eds. London: Routledge, 1993.

[47] K. Weiermair, "Tourists' perceptions towards and satisfaction with service quality in the cross-cultural service encounter: Implications for hospitality and tourism management," Managing Service Quality: An International Journal, vol. 10, no. 6, pp. 397-409, Dec. 2000.

[48] N. K. Malhotra, Marketing research: An applied orientation, 6th ed. United States: Prentice Hall, 2009.

[49] United Nation World Tourism Organization, Collection of Domestic Tourism Statistics. Madrid, Spain: United Nation World Tourism Organization, 1995.

[50] W. G. Zikmund and B. J. Babin, Business research methods, International ed. United States: South-Western, 2009.

[51] J. B. R. Ritchie and C. R. Goeldner, Travel, tourism, and hospitality research: A handbook for managers and researchers, 2nd ed. New York: John Wiley \& Sons, 1994.

[52] MORI, "UK consumer's attitudes of package holidays and their buying behaviour," MORI, Sep. 2002. [Online]. Available: http://www.odi.org.uk/sites/odi.org.uk/files/odi-assets/publicationsopinion-files/3798.pdf. Accessed: Mar. 05, 2016.

[53] Buswell, R. (1996) "Tourism in the Balearic Islands," in Tourism in Spain: critical issues, B. J. Towner and M. T. Newton, Eds. Spain: CAB International.

[54] K. G. Debbage, "Spatial behavior in a bahamian resort," Annals of Tourism Research, vol. 18, no. 2, pp. 251-268, Jan. 1991.

[55] C. Tosun, "Host perceptions of impacts: A comparative tourism study," Annals of Tourism Research, vol. 29, no. 1, pp. 231-253, Jan. 2002.

[56] T. Ratz, "Residents' perception of the sociocultural impacts of tourism at Lake Balaton, Hungary," in Tourism and Sustainable Community Development, G. Richards and D. Hall, Eds. London: Routledge, 2000, pp. 36-47.

[57] F. Gezici, "Components of sustainability: Two cases from Turkey," Annals of Tourism Research, vol. 33, no. 2, pp. 442-455, Apr. 2006.

[58] A. Franzen, "Environmental attitudes in international comparison: An analysis of the ISSP surveys 1993 and 2000," Social Science Quarterly, vol. 84, no. 2, pp. 297-308, Jun. 2003.

[59] R. Y. K. Chan, "Environmental attitudes and behavior of consumers in china," Journal of International Consumer Marketing, vol. 11, no. 4, pp 25-52, Oct. 1999.

[60] K. Manaktola, "Exploring consumer attitude and behaviour towards green practices in the lodging industry in India," International Journal of Contemporary Hospitality Management, vol. 19, no. 5, pp. 364-377, Jul. 2007.

[61] E. Aguiló, J. Alegre, and M. Sard, "The persistence of the sun and sand tourism model," Tourism Management, vol. 26, no. 2, pp. 219-231, Apr. 2005.

[62] A. Scott, M. Christie, and H. Tench, "Visitor payback: Panacea or pandora's box for conservation in the UK?," Journal of Environmental Planning and Management, vol. 46, no. 4, pp. 583-604, Jul. 2003.

[63] G. Lindsey and A. Holmes, "Tourist support for Marine Protection in Nha Trang, Viet Nam,"Journal of Environmental Planning and Management, vol. 45, no. 4, pp. 461-480, Jul. 2002.

[64] S. Dolnicar, G. I. Crouch, and P. Long, "Environment-friendly tourists: What do we really know about them?," Journal of Sustainable Tourism, vol. 16, no. 2, pp. 197-210, Feb. 2008.

[65] M. Ma and R. Hassink, "An Evolutionary Perspective On Tourism Area Development," Annals of Tourism Research, vol. 41, pp. 89-109, Apr. 2013.

[66] A. Reiser and D. G. Simmons, "A Quasi-experimental method for testing the effectiveness of Ecolabel promotion," Journal of Sustainable Tourism, vol. 13, no. 6, pp. 590-616, Nov. 2005. 